\title{
Source apportionment of fine PM and sub-micron particle number concentrations at a regional background site in the western Mediterranean: a 2.5 year study
}

\author{
M. Cusack ${ }^{1,2}$, N. Pérez ${ }^{1}$, J. Pey ${ }^{1}$, A. Alastuey ${ }^{1}$, and X. Querol ${ }^{1}$ \\ ${ }^{1}$ Institute of Environmental Assessment and Water Research, IDÆA, CSIC, C/ Jordi Girona, 18-26, 08034, Barcelona, Spain \\ ${ }^{2}$ Institute of Environmental Science and Technology (ICTA), Universitat Autónoma de Barcelona, 08193, Bellaterra, \\ Barcelona, Spain
}

Correspondence to: M. Cusack (michael.cusack@idaea.csic.es)

Received: 4 December 2012 - Published in Atmos. Chem. Phys. Discuss.: 13 February 2013

Revised: 11 April 2013 - Accepted: 25 April 2013 - Published: 22 May 2013

\begin{abstract}
The chemical composition and sources of ambient fine particulate matter $\left(\mathrm{PM}_{1}\right)$ over a period of 2.5 years for a regional background site in the western Mediterranean are presented in this work. Furthermore, sub-micron particle number concentrations and the sources of these particles are also presented. The mean $\mathrm{PM}_{1}$ concentration for the measurement period was $8.9 \mu \mathrm{g} \mathrm{m}^{-3}$, with organic matter $(\mathrm{OM})$ and sulphate comprising most of the mass $(3.2$ and $1.5 \mu \mathrm{g} \mathrm{m}^{-3}$ respectively). Six sources were identified in $\mathrm{PM}_{1}$ by Positive Matrix Factorisation (PMF): secondary organic aerosol, secondary nitrate, industrial, traffic + biomass burning, fuel oil combustion and secondary sulphate. Typically anthropogenic sources displayed elevated concentrations during the week with reductions at weekends. Nitrate levels were elevated in winter and negligible in summer, whereas secondary sulphate levels underwent a contrasting seasonal evolution with highest concentrations in summer, similar to the fuel oil combustion source. The SOA source was influenced by episodes of sustained pollution as a result of anticyclonic conditions occurring during winter, giving rise to thermal inversions and the accumulation of pollutants in the mixing layer. Increased levels in summer were owing to higher biogenic emissions and regional recirculation of air masses. The industrial source decreased in August due to decreased emissions during the vacation period. Increases in the traffic + biomass burning source were recorded in January, April and October, which were attributed to the occurrence of the aforementioned pollution episodes and local biomass burning emission sources, which include agriculture and do-
\end{abstract}

mestic heating systems. Average particle number concentrations $\left(\mathrm{N}_{9-825} \mathrm{~nm}\right)$ from $5 / 11 / 2010$ to $01 / 06 / 2011$ and from $15 / 10 / 2011$ to $18 / 12 / 2011$ reached $3097 \mathrm{~cm}^{-3}$. Five emission sources of particle of sub-micron particles were determined by Principal Component Analysis (PCA); industrial + traffic + biomass burning, new particle formation + growth, secondary sulphate + fuel oil combustion, crustal material and secondary nitrate. The new particle formation + growth source dominated the particle number concentration (56\% of total particle number concentration), especially for particles $<100 \mathrm{~nm}$, followed by industrial + traffic + biomass burning $(13 \%)$. Secondary sulphate + fuel oil combustion $(8 \%)$, nitrate $(9 \%)$ and crustal material $(2 \%)$ were dominant for particles of larger diameter $(>100 \mathrm{~nm})$ and thus did not influence the particle number concentration significantly.

\section{Introduction}

The negative impacts of particulate matter (PM) on human health have been well established in literature (Pope and Dockery, 2006). Furthermore, the ability of ambient PM to impact the Earth's climate (IPCC, 2007), visibility and natural ecosystems has made it the focus of intensive study for many decades now. Current legislation in Europe enforces controls on emissions and ambient levels of $\mathrm{PM}_{10}$ (particles of diameter $<10 \mu \mathrm{m})$ and $\mathrm{PM}_{2.5}(<2.5 \mu \mathrm{m})$, such as the European Directive 2008/50/EC. Particle size is an important factor when considering the ability of particles to penetrate 
into the human respiratory system (Lighty et al, 2000) and the fine fraction $\left(\mathrm{PM}_{1}\right)$ and sub-micron particle number concentration may be more detrimental to human health owing to their capacity to penetrate deeper into the lungs. Despite this fact, the fine PM fraction and its chemical composition remain relatively understudied, especially outside urban areas. In recent years much attention has been focused on the aerosol sub-micron particle number concentration, which has been shown to have an inverse relationship with mass (Rodríguez et al., 2007; Pey et al., 2008). This implies that a reduction of ambient PM concentrations, as encouraged by pollution abatement strategies, might actually increase sub-micrometer particle number concentrations. Thus, understanding the chemical composition and sources of fine $\mathrm{PM}$ and sub-micron particles is vital. Of the few studies performed on $\mathrm{PM}_{1}$, most are concerned with the urban environment, and were characterised during short measurement campaigns (Vecchi et al., 2008; Richard et al., 2011). Cozic et al. (2008) published results on organic and inorganic compounds in $\mathrm{PM}_{1}$ for 7 years at a high alpine site in Switzerland (Jungfraujoch). Bourcier et al. (2012) studied PM PMn- $_{1}$ con centrations and seasonal variability over one year at the high altitude site of puy de Dôme in France. However, of the studies mentioned, source apportionment was only performed for $\mathrm{PM}_{1}$ at urban sites by Vecchi et al. (2008) and Richard et al. (2011). Minguillón et al. (2012) performed source apportionment of $\mathrm{PM}_{1}$ at a rural site in Switzerland but only for short measurement campaigns during summer and winter. Source apportionment studies are important to help identify the major pollution sources affecting ambient PM and particle number concentrations. The characterisation of the sources of sub-micron particles has been performed in urban environments using Principal Component Analysis (Pey et al., 2009b) and Positive Matrix Factorisation (Harrison et al., 2011).

The accumulation of a relatively long series of $\mathrm{PM}_{1}$ levels and chemical composition data in this study (September 2009 to January 2012) has allowed for the investigation of the daily and seasonal variation in $\mathrm{PM}_{1}$ and the identification of a number of sources affecting $\mathrm{PM}_{1}$ at a regional background site in the western Mediterranean. Furthermore, in the present study a large number of parameters, including $\mathrm{PM}_{1}$ chemical components, gaseous pollutants and meteorological variables have been combined with particle number size distribution in order to identify and quantify the contribution of various sources to atmospheric sub-micron particle concentrations. To the author's knowledge, no similar study exists in the literature for regional background sites.

\section{Methodology}

\subsection{Sampling site}

Regular sampling of $\mathrm{PM}_{1}$ for gravimetric analysis was performed at a regional background (RB) site in the North East of the Iberian Peninsula. The site Montseny (MSY; $41^{\circ} 46^{\prime} \mathrm{N}$, $02^{\circ} 21^{\prime} \mathrm{E}, 720$ m.a.s.l.) is located in the Montseny natural park, $40 \mathrm{~km}$ from the greater urbanised area of Barcelona and $25 \mathrm{~km}$ from the Mediterranean coast. The mountainous region in which the site is located is sparsely populated and densely forested, but pollution from the region affects the area regularly, which is especially influenced by mesoscale and synoptic meteorology. The cyclical nature of prevailing mountain and sea breezes can transport urban and industrial emissions from the densely populated valleys and depressions below MSY to the site. Furthermore, MSY can be subjected to sustained episodes of pollution during winter (winter anticyclonic episodes; WAE), whereby calm weather creates a stagnant air mass and the accumulation of aerosols, increasing pollutant levels substantially. These pollution episodes (associated with anticyclonic pressure systems) tend to persist until removed by less calm weather such as strong winds which disperse the air mass. In summer, high pressure systems and insolation create regional recirculation of air masses, causing the aging and recirculation of air masses containing aerosols, particularly ammonium sulphate, over a larger area. Furthermore, episodes of Saharan dust intrusions are more frequent in summer, although they can occur year-round. Lower rainfall in summer also promotes the resuspension of soils and intensified solar radiation increases biogenic emissions and photochemical reactions of aerosols (Seco et al., 2011). These factors combined result in generally higher aerosol levels across the region for the summer months. Winter time levels are comparatively lower owing to higher precipitation and Atlantic advection, except when anticyclonic conditions prevail. For further information and details on atmospheric dynamics and PM trends at MSY see Pérez et al. (2008), Pey et al. (2010) and Cusack et al. (2012).

\subsection{Measurements}

Samples of $\mathrm{PM}_{1}$ were collected on quartz fibre filters (Pallflex) consecutively every four days from September 2009 to January 2012 with high volume samplers $\left(30 \mathrm{~m}^{3} \mathrm{~h}^{-1}\right)$ DIGITEL-DH80, equipped with a $\mathrm{PM}_{1}$ cut-off inlet (also DIGITEL). 182 samples were collected in total. Filter pre-treatment consisted of oven-baking the filters at $200^{\circ} \mathrm{C}$ for $4 \mathrm{~h}$ to remove impurities, followed by conditioning for $24 \mathrm{~h}$ at $20-25^{\circ} \mathrm{C}$ and $25-30 \%$ relative humidity. Following sampling, the filters were weighed three times on three consecutive days. PM mass concentrations were determined by standard gravimetric procedures, and complete 
chemical analysis for all filters was performed following the procedures described by Querol et al. (2001).

Chemical analysis was performed by a range of instrumental techniques to determine concentrations of various elements and components. Acid digestion ( $\mathrm{HF}: \mathrm{HNO}_{3}: \mathrm{HClO}_{4}$ ) of $1 / 2$ of each filter was carried out and subsequently analysed by Inductively Coupled Plasma Atomic Emission Spectroscopy, ICP-AES (IRIS Advantage TJA solutions, THERMO) to determine concentrations of major components ( $\mathrm{Al}, \mathrm{Ca}, \mathrm{Na}, \mathrm{Mg}, \mathrm{Fe}, \mathrm{K})$. Trace element concentrations were determined by means of Inductively Coupled Plasma Mass Spectroscopy, ICP-MS (X Series II, THERMO). 1/4 of the filter was analysed for water soluble ions $\mathrm{SO}_{4}^{2-}, \mathrm{NO}_{3}^{-}$, $\mathrm{NH}_{4}^{+}$and $\mathrm{Cl}^{-}$and analysed by Ion Chromatography HPLC (High Performance Liquid Chromatography) using a WATERS IC-pakTM anion column and WATERS 432 conductivity detector. $\mathrm{NH}_{4}^{+}$was determined by an ion specific electrode. Organic and Elemental Carbon (OC and EC) were measured using the remaining $1 / 4$ of each filter by a thermaloptical transmission technique using a Sunset Laboratory OCEC Analyser. The EUSAAR2 protocol was employed (as outlined by Cavalli et al., 2010). Organic Matter (OM) is calculated from $\mathrm{OC}$ by multiplying by a factor of 2.1 as suggested by Turpin et al. (2001) and Aiken et al., (2005). $\mathrm{SiO}_{2}$ and $\mathrm{CO}_{3}^{2-}$ were indirectly determined from empirical formulas (Querol et al., 2001). A complete dataset of major components (OC, $\mathrm{EC}, \mathrm{NO}_{3}^{-}, \mathrm{SO}_{4}^{2-}, \mathrm{NH}_{4}^{+}, \mathrm{Cl}^{-} \mathrm{Al}, \mathrm{Ca}, \mathrm{Na}, \mathrm{Mg}$, $\mathrm{Fe}$ and $\mathrm{K}$ ) and trace elements (Ti, $\mathrm{V}, \mathrm{Cr}, \mathrm{Mn}, \mathrm{Ni}, \mathrm{Cu}, \mathrm{Zn}$, $\mathrm{As}, \mathrm{Rb}, \mathrm{Sr}, \mathrm{Cd}, \mathrm{Sn}, \mathrm{Sb}, \mathrm{La}, \mathrm{Pb}$, among others) was thus compiled. Crustal material was determined from the sum of concentrations of $\mathrm{Al}_{2} \mathrm{CO}_{3}, \mathrm{SiO}_{2}, \mathrm{CO}_{3}^{2-}, \mathrm{Ca}, \mathrm{K}, \mathrm{Mg}$ and $\mathrm{Fe}$. Sea spray was determined from the sum of $\mathrm{Na}^{+}$and $\mathrm{Cl}^{-}$. The combined sum of the determined chemical components accounted for almost $70 \%$ of the total PM mass. For each set of ten filters, nine were sampled and one was reserved for blank analysis. The corresponding blank filter was analysed using the same procedures described for OC/EC, water soluble ions and for major/minor elements. Blank concentrations were subtracted from the total concentration measured for each sample, thus giving ambient concentrations.

Sub-micron particle number size distribution was measured using a mobility particle size spectrometer operated in the scanning mode. In the following article, we call the system a Scanning Mobility Particle Sizer (SMPS). The SMPS system comprises a Differential Mobility Analyzer (DMA) connected to a Condensation Particle Counter (CPC, Model TSI 3772). The DMA system was designed and manufactured in the framework of EUSAAR project at the Leibniz Institute for Tropospheric Research (IfT) in Leipzig, Germany. The SMPS system provided a complete particle number size distribution of the number of particles between 9 and $825 \mathrm{~nm}$ $\left(\mathrm{N}_{9-825}\right)$, and completed one scan every five minutes. Prior to sampling, the aerosol is dried using a nafion dryer in order to maintain a relative humidity below $40 \%$. The sampled aerosol flow was maintained at $11 \mathrm{~min}^{-1}$ at the inlet and the dried sheath air flow was maintained at $51 \mathrm{~min}^{-1}$.

Black Carbon (BC) concentrations were measured continuously using a Multi Angle Absorption Photometer (MAAP, model 5012, Thermo). Real time measurements of $\mathrm{O}_{3}$, NO, $\mathrm{NO}_{2}, \mathrm{CO}$ and $\mathrm{SO}_{2}$ were obtained on-site, supplied by the Department of the Environment of the Autonomous Government of Catalonia. Hourly levels of wind direction, wind speed, solar radiation, temperature, relative humidity and precipitation were recorded in real-time on site. See Pérez et al. (2008) for further details. Solar radiation is presented in this work as the sum of hourly averages of solar radiation.

\subsection{Source apportionment}

\subsubsection{Positive Matrix Factorisation}

Source apportionment analysis was performed on the data set of $\mathrm{PM}_{1}$ using Positive Matrix Factorisation (PMF) by means of EPA PMF v3.0 software. PMF is a multivariate tool used to determine source profiles by decomposing a matrix of data composed of chemical species into two matrices - factor contributions and factor profiles. The method employed in this work is based on that described by Paatero and Taper (1994). Individual estimates of the uncertainty associated with each data value are required as PMF is a weighted least-squares method. The individual estimates of uncertainty in the data set were determined following the methodology described by Amato et al. (2009). This methodology is similar to that described by Thompson and Howarth (1976), but also considers the uncertainty associated with blank filter subtraction from each sample. Elements used in this study $\left(\mathrm{OC}, \mathrm{SO}_{4}^{2-}\right.$, $\mathrm{NO}_{3}^{-}, \mathrm{NH}_{4}^{+}, \mathrm{EC}, \mathrm{Al}, \mathrm{Ca}, \mathrm{K}, \mathrm{Na}, \mathrm{Mg}, \mathrm{Fe}, \mathrm{Mn}, \mathrm{Ti}, \mathrm{V}, \mathrm{Cr}, \mathrm{Ni}$, $\mathrm{Cu}, \mathrm{Zn}, \mathrm{As}, \mathrm{Rb}, \mathrm{Sr}, \mathrm{Cd}, \mathrm{Sn}, \mathrm{Sb}, \mathrm{Pb}$ and $\mathrm{La}$ ) were selected according to their signal to noise ratio $(\mathrm{S} / \mathrm{N})$, whereby species with $\mathrm{S} / \mathrm{N}<2$ were defined as weak, and species with $\mathrm{S} / \mathrm{N}>2$ defined as strong. These criteria resulted in 12 strong species and 15 weak species. The total $\mathrm{PM}_{1}$ concentration was set as the "total variable" and thus automatically categorised as "weak", increasing the uncertainty of this variable by a factor of three so as not to affect the PMF solution. In total, the matrix included 182 cases. After a variety of factor numbers were tested, it was observed that a 6 factor solution provided the most meaningful results, with a correlation coefficient $\left(R^{2}\right)$ of 0.71 between the modelled and experimental $\mathrm{PM}_{1}$ concentrations, with $\mathrm{Q}$ values of 2816 (Robust) and 2833 (True). Correlation coefficients $\left(R^{2}\right)$ between modelled and measured concentrations for OC, sulphate and nitrate were $0.97,0.95$ and 0.99 respectively. These $Q$ values were investigated for different FPEAK values, with FPEAK $=0$ found to be the most reasonable. 100 bootstrap runs with a minimum $R^{2}$ of 0.6 were also performed to test the uncertainty of the resolved profiles, with all 6 factors being mapped, verifying the stability of the results. 


\subsubsection{Principal component analysis}

Principal component analysis (PCA) was performed using the software STATISTICA v4.2. The orthogonal transformation method with Varimax rotation was employed, retaining principal components with eigenvalues greater than one. The dataset used for PCA was comprised of the $\mathrm{PM}_{1}$ total mass and its constituents $\mathrm{OC}, \mathrm{EC}, \mathrm{Al}_{2} \mathrm{O}_{3}, \mathrm{Ca}, \mathrm{Fe}, \mathrm{K}, \mathrm{Mg}, \mathrm{Na}$, $\mathrm{SO}_{4}^{2-}, \mathrm{NO}_{3}^{-}, \mathrm{NH}_{4}^{+}, \mathrm{Ti}, \mathrm{V}, \mathrm{Mn}, \mathrm{Ni}, \mathrm{Cu}, \mathrm{Zn}, \mathrm{As}, \mathrm{Cd}, \mathrm{Sn}, \mathrm{Sb}$, $\mathrm{La}, \mathrm{Ce}$ and $\mathrm{Pb}$. The following variables were also included: $\mathrm{NO}_{2}, \mathrm{SO}_{2}, \mathrm{BC}$, temperature, solar radiation and wind speed. Particle number concentrations were calculated for different size bins; $\mathrm{N}_{9-30}, \mathrm{~N}_{30-50}, \mathrm{~N}_{50-100}, \mathrm{~N}_{100-300}, \mathrm{~N}_{300-500}$, $\mathrm{N}_{500-825}$. Days whereby simultaneous measurements of particle number size distribution and chemical analysis were performed were included for PCA analysis, which totalled 61 cases, from $05 / 11 / 2010$ to $01 / 06 / 2011$ and from $15 / 10 / 2011$ to $18 / 12 / 2011$ (the instrument was under repair from June to October 2011). A typical robust PCA analysis requires a large dataset ( $>100$ cases), which is significantly more than presented in this work, and therefore the reduced dataset may propose a limitation in the data analysis presented. This technique allows for the identification of potential sources (principal components) with respect to the particle number concentration in different size ranges. Furthermore, a multilinear regression analysis (MLRA) allows for the calculation of the daily contribution of each source to the particle number concentration following the methodology proposed by Thurston and Spengler (1985) and Pey at al. (2009b). MLRA was applied to the data set using the particle number concentrations in each of the aforementioned size bins as the dependent variables and the principal component factor scores as the independent variables. The comparison between the experimental number concentration and the modelled concentration provided good correlation $\left(R^{2}=0.86\right)$.

\section{Results and Discussion}

\subsection{PM concentrations and composition}

The average $\mathrm{PM}_{1}$ concentrations (arithmetic mean) for the entire measurement period (24/09/2009 to11/01/2012) were $8.9 \pm 4 \mu \mathrm{g} \mathrm{m}^{-3}$. $\mathrm{PM}_{1}$ concentrations at MSY undergo a clear seasonality with minimum concentrations in winter $\left(6.6 \mu \mathrm{g} \mathrm{m}^{-3}\right)$, followed by autumn $\left(7.6 \mu \mathrm{g} \mathrm{m}^{-3}\right)$, spring $\left(9.4 \mu \mathrm{g} \mathrm{m}^{-3}\right)$ and summer $\left(11.2 \mu \mathrm{g} \mathrm{m}^{-3}\right)$. OM is the largest component of $\mathrm{PM}_{1}\left(3.2 \mu \mathrm{g} \mathrm{m}^{-3} ; 37 \%\right)$, as shown in Fig. 1 . OM sources at MSY are varied, but are mostly attributed to secondary organic aerosol (SOA) produced from anthropogenic volatile organic compounds (VOCs) emitted from industry and road traffic, mixed anthropogenic/natural sources such as biomass burning, and natural sources such as biogenic emissions (Seco et al., 2011). Sulphate is the second most abundant compound in $\mathrm{PM}_{1}\left(1.5 \mu \mathrm{g} \mathrm{m}{ }^{-3} ; 16 \%\right)$

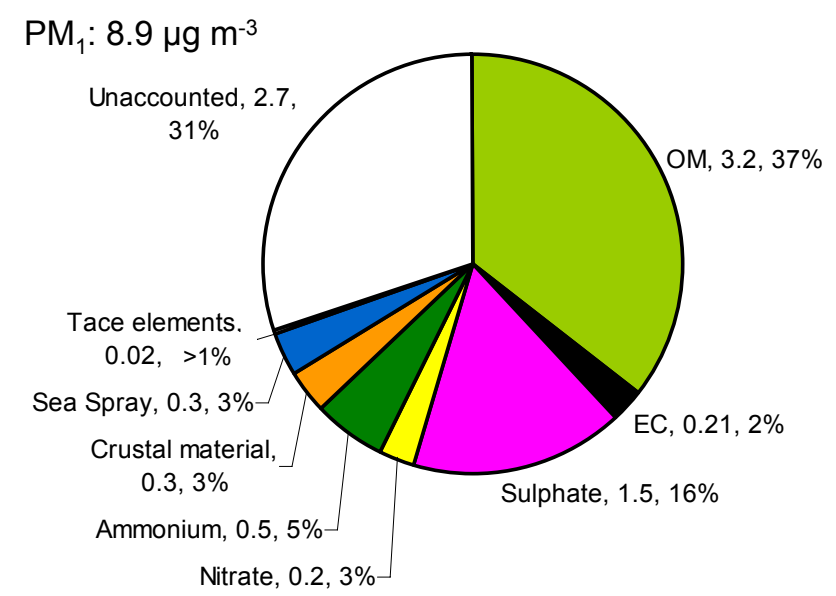

Fig. 1. Chemical composition of $\mathrm{PM}_{1}$ at MSY from 24/09/2009 to $11 / 01 / 2012$.

and is associated with power generation, industrial and shipping emissions, followed by ammonium $\left(0.5 \mu \mathrm{g} \mathrm{m}^{-3} ; 5 \%\right)$ and nitrate $\left(0.2 \mu \mathrm{g} \mathrm{m}^{-3} ; 3 \%\right)$. Nitrate concentrations are significantly elevated in winter and much lower in summer owing to its thermal instability (Harrison and Pio, 1983, Querol et al, 2001). Ammonium nitrate can be volatilised in the atmosphere in warmer conditions associated with the Mediterranean climate, especially in summer. However, a negative artefact may also account for the reduced concentrations measured in summer, due to the volatilisation of ammonium nitrate from the filter during and after sampling. Crustal material, sea spray and EC (from traffic and biomass burning emissions) make up the remainder of the major components of $\mathrm{PM}_{1}$, with concentrations of $0.3,0.3$ and $0.21 \mu \mathrm{g} \mathrm{m}^{-3}$ respectively. The sum of trace element concentrations is $0.02 \mu \mathrm{g} \mathrm{m}^{-3}$.

Long term $\mathrm{PM}_{1}$ measurements at $\mathrm{RB}$ sites are relatively scarce in literature. Long term measurements of $\mathrm{PM}_{1}$ were performed at a high altitude site (Jungfraujoch, 3580 m.a.s.l.) in Switzerland (Cozic et al., 2008). A clear seasonality for chemical components was observed at the site with low concentrations during winter owing to the residence of the site in the free troposphere, and higher concentrations in summer owing to enhanced vertical transport of boundary layer pollutants. A similar seasonality was observed for $\mathrm{PM}_{1}$ at puy de Dôme (1465 m.a.s.l.) with higher summer concentrations and a winter minimum (Bourcier et al., 2012). Both these sites are high altitude sites, at higher altitudes than MSY (720 m.a.s.l.), and are considerably more influenced by free tropospheric air, although MSY exhibits a similar seasonal trend. Spindler et al. (2010) reported average concentrations of $12-13 \mu \mathrm{g} \mathrm{m}^{-3}$ of $\mathrm{PM}_{1}$ for a RB site in Germany (Melpitz). A study by Minguillón et al. (2012) compared $\mathrm{PM}_{1}$ concentrations at a RB site in Switzerland (Payerne) for one month in winter and in summer. The concentrations of $\mathrm{PM}_{1}$ at this site were $12 \mu \mathrm{g} \mathrm{m}^{-3}$ and $6 \mu \mathrm{g} \mathrm{m}^{-3}$ in winter and 


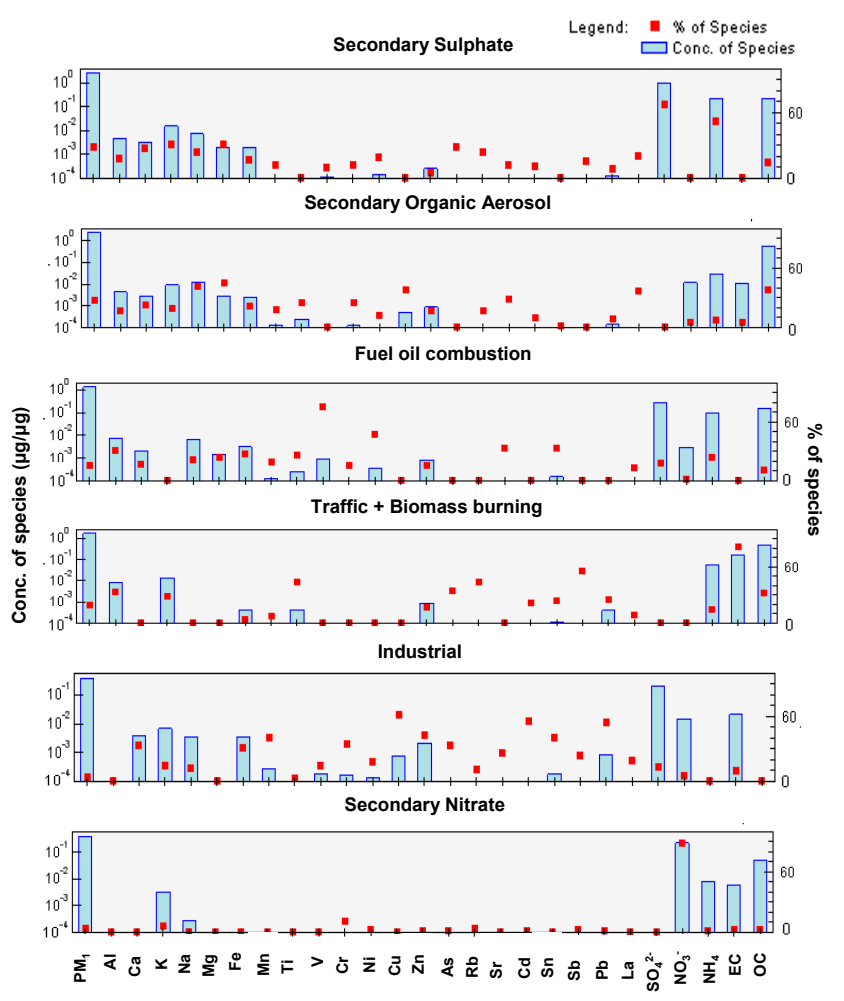

Fig. 2. Source profiles $(\mu \mathrm{g} / \mu \mathrm{g})$ identified for $\mathrm{PM}_{1}$ measured at MSY. All available $\mathrm{PM}_{1}$ samples (182) were used. The mass of each species apportioned to the factor (blue bar, left axis) and the percent of each species apportioned to each factor (red square, right axis) is shown.

summer respectively (overall mean of $9 \mu \mathrm{g} \mathrm{m}^{-3}$ ). The winter maximum at Payerne is a result of increased biomass burning emissions and intense thermal inversions, causing the accumulation of pollutants in populated valleys. These seasonal concentrations are in contrast to MSY, whereby winter concentrations are lower $\left(6.6 \mu \mathrm{g} \mathrm{m}^{-3}\right)$ than in summer $\left(11.2 \mu \mathrm{g} \mathrm{m}^{-3}\right)$. At MSY, all components give the lowest concentrations in winter and highest in summer, except for nitrate and sea spray (Table 1). EC concentrations were also lowest in summer but highest in the autumn.

This winter to summer increase in $\mathrm{PM}_{1}$ can be attributed to the year-round dominance of $\mathrm{SO}_{4}^{2-}$ and $\mathrm{OM}$ concentrations on the overall mass. Sulphate and OM levels are higher during summer owing to; enhanced photochemistry associated with more intense solar radiation, lower air mass renovation on a regional scale (Rodríguez et al., 2003), and the increase of the mixing layer height giving higher regional transport that favours the regional mixing of polluted air masses (Pey et al., 2009a). Furthermore, biogenic emissions from surrounding vegetation at MSY in summer are considerably increased, affecting OM concentrations (Seco et al., 2011).

Increased levels of sulphate, ammonium, OM, EC and nitrate can also occur under specific atmospheric conditions



Fig. 3. Average contribution of each source $\left(\mu \mathrm{g} \mathrm{m}^{-3}\right)$ to $\mathrm{PM}_{1}$ obtained by PMF.

such as WAE, whereby calm, cold, sunny weather favours the stagnation of air masses and accumulation of pollutants over several days (Pey et al., 2010). During these episodes, pollution that has accumulated around the industrialised and urbanised valleys below MSY is carried to the site by mountain breezes during the day, with cleaner tropospheric air present at night when the breeze retreats.

\subsection{Source contribution to ambient PM levels}

\subsubsection{Identification of emission sources by PMF}

Twenty six $\mathrm{PM}_{1}$ chemical species with a signal to noise ration $(\mathrm{S} / \mathrm{N})$ greater than 0.2 were used in order to identify various sources. Six $\mathrm{PM}_{1}$ sources were identified by PMF analysis. Figure 2 shows the source profiles and the percentages of ambient species concentration apportioned by each source.

The six $\mathrm{PM}_{1}$ sources, in order of contribution to the $\mathrm{PM}_{1}$ mass (Fig. 3) were: secondary sulphate $\left(2.63 \pm 2.85 \mu \mathrm{g} \mathrm{m}^{-3}\right)$, secondary organic aerosol (SOA; $2.47 \pm 1.84 \mu \mathrm{g} \mathrm{m}^{-3}$ ), fuel oil combustion $\left(1.46 \pm 1.41 \mu \mathrm{g} \mathrm{m}^{-3}\right)$, traffic + biomass burning $\left(1.12 \pm 0.83 \mu \mathrm{g} \mathrm{m}^{-3}\right)$, industrial $\left(0.39 \pm 0.33 \mu \mathrm{g} \mathrm{m}^{-3}\right)$ and secondary nitrate $\left(0.44 \pm 1.13 \mu \mathrm{g} \mathrm{m}^{-3}\right)$. Although OM was identified as the major component of $\mathrm{PM}_{1}$, SOA was not found to explain the largest variance in $\mathrm{PM}_{1}$, probably because OC levels were consistently high (and less variable) compared to other components, thus reducing the explained variance of $\mathrm{PM}_{1}$ by the $\mathrm{SOA}$ source. Thus, the secondary sulphate source accounted for the largest variance in $\mathrm{PM}_{1}$ $(28 \%)$. Secondary sulphate is characterised mostly by ammonium sulphate, and accounts for $55 \%$ of the variance of ammonium. Ammonium sulphate is associated with pollution across the region, when atmospheric recirculation causes the accumulation and aging of pollutants, especially in summer (Fig. 4). It is also characterised by many other components associated with both crustal elements (Al, $\mathrm{Ca}, \mathrm{La}, \mathrm{Mg}$, $\mathrm{Fe}$ ) and anthropogenic emissions (EC, As, Sb), highlighting the regional nature of this factor. A crustal source was not specifically identified by PMF analysis, but the presence of 
Table 1. Mean annual and seasonal concentrations for major components of $\mathrm{PM}_{1}$ at MSY, and sum of concentrations of trace elements (TE), in $\mu \mathrm{g} \mathrm{m}^{-3}$.

\begin{tabular}{llllllllll}
\hline & $\mathrm{PM}_{1}$ & Crustal & Sea Spray & $\mathrm{SO}_{4}^{2-}$ & $\mathrm{NO}_{3}^{-}$ & $\mathrm{NH}_{4}^{+}$ & $\mathrm{EC}$ & $\mathrm{OM}$ & $\sum \mathrm{TE}$ \\
\hline Annual & 8.9 & 0.3 & 0.3 & 1.5 & 0.2 & 0.5 & 0.21 & 3.2 & 0.021 \\
Spring & 9.4 & 0.3 & 0.2 & 1.3 & 0.2 & 0.4 & 0.22 & 2.9 & 0.018 \\
Summer & 11.2 & 0.4 & 0.4 & 2.4 & 0.1 & 0.7 & 0.16 & 3.8 & 0.028 \\
Autumn & 7.6 & 0.3 & 0.2 & 1.4 & 0.1 & 0.5 & 0.24 & 3.2 & 0.020 \\
Winter & 6.6 & 0.2 & 0.5 & 0.6 & 0.6 & 0.4 & 0.22 & 2.8 & 0.016 \\
\hline
\end{tabular}

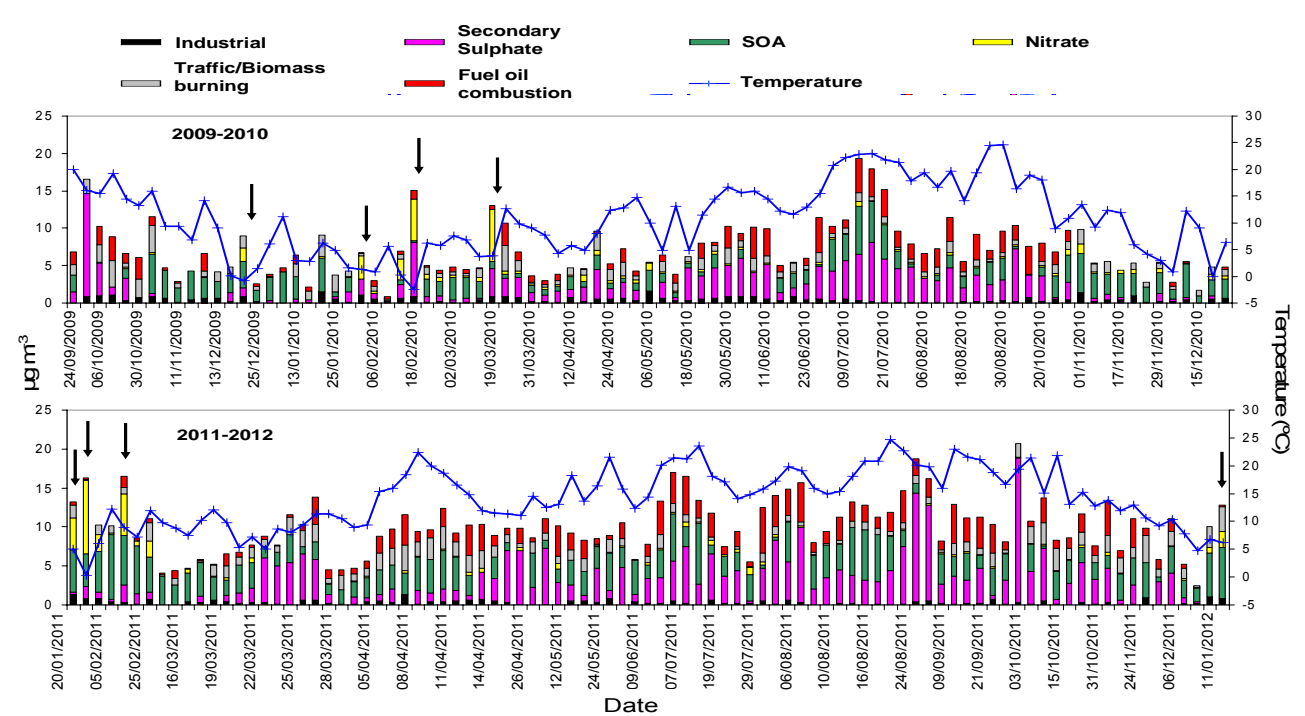

Fig. 4. Daily contribution of each source to total $\mathrm{PM}_{1}$ mass concentration $\left(\mu \mathrm{g} \mathrm{m}^{-3}\right.$ ) and temperature $\left({ }^{\circ} \mathrm{C}\right)$ for $24 / 09 / 2009$ to $19 / 12 / 2010$ (above) and 20/01/2011 to 11/01/2012 (below). Intense winter pollution episodes are marked by black arrows.

crustal material was observed in both the secondary sulphate source and the SOA source. This is likely due to seasonal and meteorological influences, as soil resuspension and Saharan dust intrusions are most common in summer (Pérez et al., 2008), also when secondary sulphate and SOA are more abundant. In verification of this theory, the secondary sulphate source also explains $19 \%$ of the variance in OC. This is probably due to the influence of summer recirculation episodes and more intense solar radiation, as emissions of OC and sulphate are likely to be independent of each other. Elevated levels of the secondary sulphate source also occur during episodes of pollution in winter such as WAE, as indicated by the arrows in Fig. 4.

The source titled SOA is the second most important source concerning $\mathrm{PM}_{1}$ mass concentrations, comprising $28 \%$ of the total mass. It is mostly characterised by OC (explaining $43 \%$ of the total variance in OC). The annual variation of this source is mostly driven by two processes; (1) as is evident in Fig. 4, this source undergoes increased levels during prolonged episodes of winter pollution, mainly as a result of SOA produced from anthropogenic VOC and possibly biomass burning emissions. For example, elevated concen- trations of SOA and nitrate were recorded at the beginning of 2011. (2) The observed increasing summer trend can be attributed to increased biogenic emissions from local vegetation, and enhanced photochemical reactions (Seco et al., 2012). A study performed by Minguillón et al. (2011) reported that the fraction of OC attributed to biomass burning at MSY in winter was $17-21 \%$ and only $12 \%$ in summer. In the same study, it was found that the fraction of OC attributed to fossil fuel consumption (mainly traffic emissions) was $34 \pm 4 \%$ and $31 \pm 4 \%$ for winter and summer respectively. Considering the clear seasonality of this source with elevated concentrations in summer, the low contribution of biomass burning to OC concentrations reported by Minguillón et al. (2011), the absence of EC in this source and the prohibition of open burning of agricultural biomass during summer (Spanish Decreto 64/1995), it can be reasonably assumed that this source is SOA with negligible input from biomass burning. As observed for the secondary sulphate source, some typical crustal elements such as La, Rb, $\mathrm{Ti}, \mathrm{Ca}, \mathrm{Al}, \mathrm{Mg}, \mathrm{Fe}$ and $\mathrm{Sr}$ are present, for the same reasons already described. 
The third most important source in terms of contribution to the $\mathrm{PM}_{1}$ mass is fuel oil combustion (17\%). This source is characterised by typical tracers $\mathrm{V}, \mathrm{Ni}$, and $\mathrm{Sn}$ (Pandolfi et al., 2011), and accounts for $19 \%$ of the variance in sulphate and $24 \%$ of ammonium, indicating that there is some overlap between the secondary sulphate source, specifically ammonium sulphate, and the fuel oil combustion source. Querol et al. (2009) reported that concentrations of $\mathrm{V}$ are elevated in the Mediterranean region owing to increased consumption of fuel oil for power generation, shipping and industrial emissions. The separation of this factor from that of secondary sulphate may give an indication of the age of the aerosol. $\mathrm{SO}_{2}$ emissions from fuel oil combustion, emitted alongside $\mathrm{V}$ and $\mathrm{Ni}$, may not be oxidised to $\mathrm{SO}_{4}^{2-}$ before reaching MSY, whereas the secondary sulphate source is older and representative of emissions across the region. This behaviour has also been observed in the Eastern Mediterranean (Öztürk et al., 2012). The presence of $\mathrm{Na}$ and $\mathrm{Mg}$, typical marine aerosols, in the fuel oil combustion source may indicate the influence of shipping emissions. A source apportionment study of $\mathrm{PM}_{10}$ and $\mathrm{PM}_{2.5}$ for the MSY site was performed by Pey et al. (2009a). In that study, the secondary sulphate and fuel oil combustion sources were not separated, but correlation was observed for secondary sulphate and sea spray emissions, indicating some influence of shipping emissions. Furthermore, it was shown that sea spray concentrations were considerably higher in summer at MSY owing to the increased sea breeze circulation over the coastal area ( $25 \mathrm{~km}$ from MSY).

The source of traffic + biomass burning (13\% of variance in $\mathrm{PM}_{1}$ ) is identified from the presence of typical traffic tracers EC, OC, Sb and Sn (Amato et al., 2009; Minguillón et al., 2012). This source explains $78 \%$ of the variance in EC. Minguillón et al. (2011) reported that 66-79\% of EC measured at MSY had a fossil origin, with the remainder attributed to biomass burning. The influence of biomass burning is highlighted by the presence of $\mathrm{K}$, a known biomass burning tracer (Pio et al., 2008). An industrial source was identified, characterised by typical industrial tracers such as $\mathrm{Pb}, \mathrm{As}, \mathrm{Cd}, \mathrm{Sn}$, $\mathrm{Cu}, \mathrm{Zn}, \mathrm{Cr}, \mathrm{Fe}$ and Mn (Viana et al., 2006; Belis et al., 2013). This source does not contribute substantially to the total PM mass $(4 \%)$ as it is mostly comprised of trace elements.

Finally, a secondary nitrate source was identified and was characterised to a very small extent by EC (3\% of the total variance of EC) and $\mathrm{K}(7 \%)$, probably as a result of mixing with aged traffic and biomass burning emissions. Some fraction of nitrate in $\mathrm{PM}_{1}$ at MSY can exist as potassium nitrate, especially during WAE. Nitrate is most abundant in winter when temperatures are lower, and negligible in summer, as shown in Fig. 4. Thus, nitrate comprises little of the total $\mathrm{PM}_{1}$ mass on a yearly basis (5\%), but its contribution to the mass increases to $19 \%$ in winter.

To the author's knowledge, there are few existing source apportionment studies on fine PM, especially at RB sites. Most existing studies were performed at urban sites, such as that of Vecchi et al. (2008) and Richard et al. (2011). In the study by Vecchi et al. (2008), PMF was performed on $\mathrm{PM}_{1}$ samples from three different urban areas across Italy, but major chemical components such as $\mathrm{OC}, \mathrm{EC}, \mathrm{NH}_{4}^{+}$and $\mathrm{NO}_{3}^{-}$ were not included. Minguillón et al. (2012) identified five sources during two month-long (summer and winter) measurement campaigns at a rural site in Switzerland, which were ammonium nitrate, ammonium sulphate $+\mathrm{K}+$ road traffic, industrial, road traffic and background $\mathrm{V}, \mathrm{Ni}$ and $\mathrm{Fe}$. This current study is the first of its kind to perform source apportionment studies on $\mathrm{PM}_{1}$ and particle number concentrations at a RB site that comprises a large database of chemical species with long term measurements.

\subsubsection{Daily and monthly variation}

Figure 5 shows the daily variation of each source. The secondary sulphate source is generally elevated during the week with a decreasing trend at weekends. It undergoes an unusual weekly cycle in that concentrations decrease on Tuesday and Wednesday, which may be a result of some seasonal fluctuations rather than reflecting the true nature of the weekly trend. Episodes of regional pollution which most influence sulphate concentrations, especially in summer, induce the accumulation of pollutants from across the region over time, independent of the time of emission, which would affect the weekly cycle. However, a weekend decrease is observed, probably owing to lower $\mathrm{SO}_{2}$ emissions on weekends. $\mathrm{SOA}$ does not undergo any discernible weekly pattern, as a large proportion of this source is natural, especially in summer. As stated previously, this source can be associated with anthropogenic activities in winter, but such seasonality is obviously not reflected in the weekly trend.

Conversely, sources identified as traffic + biomass burning, fuel oil combustion and industrial all undergo a marked weekly evolution with increasing concentrations throughout the week followed by a considerable reduction at weekends, when traffic flow and industrial activity would be diminished. Finally, the nitrate source undergoes a similar variation to that of traffic + biomass burning and the industrial source, with increasing concentrations during the week followed by minimum values at weekends.

The monthly variation of each source highlights the influence of meteorology and anthropogenic activities on each source (Fig. 6). The secondary sulphate source undergoes a clear monthly variation with highest concentrations recorded in summer, owing to the aforementioned regional pollution episodes and more intense insolation. Secondary sulphate concentrations in winter are reduced, when nitrate concentrations are at their highest, highlighting the thermal instability of particulate nitrate. Traffic + biomass burning is highest in January, April and October. Traffic emissions throughout the year should remain relatively constant, thus the observed variation must be due to other variable factors such as the aforementioned WAE and the influence of local meteorology (mountain breezes, thermal inversions), and also to 


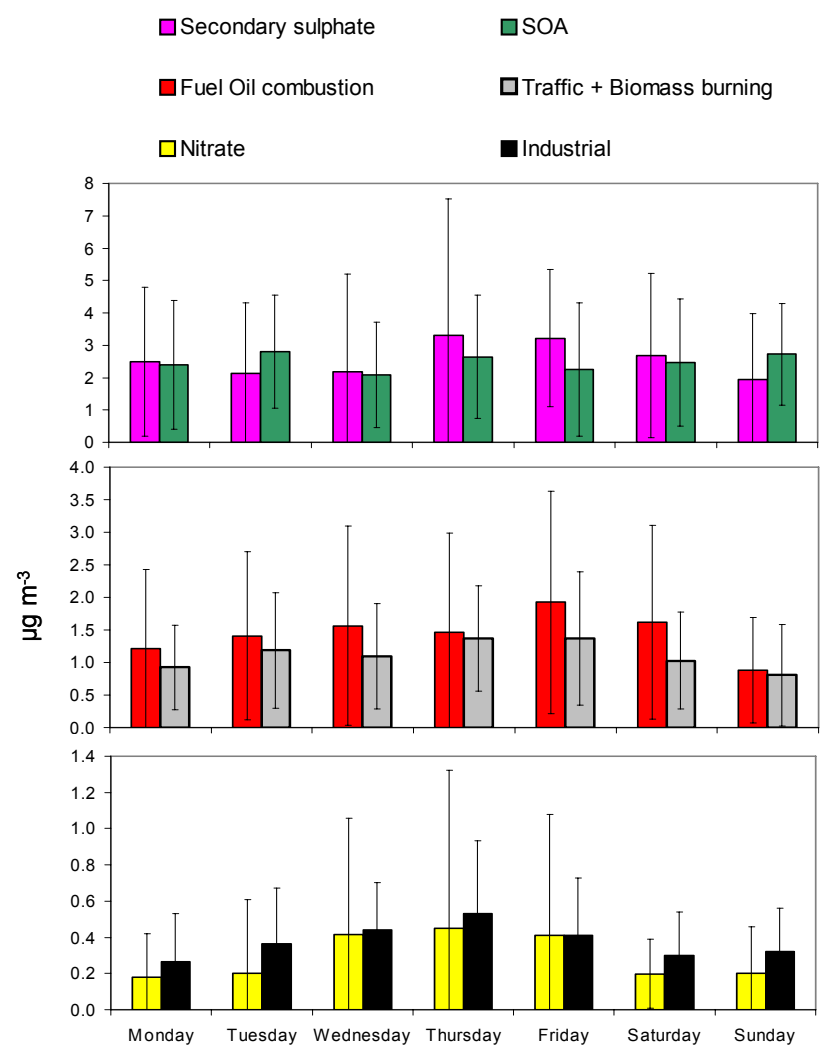

Fig. 5. Average daily concentrations $\left(\mu \mathrm{g} \mathrm{m}^{-3}\right)$ of each source.

some extent emissions from biomass burning. The peak observed in January may be directly related to local emissions from domestic heating systems. The peaks observed in April and October may be explained by controlled biomass burning from local agriculture, which is common during these months. The impact of this factor is reduced at the height of summer (July and August), when biomass burning is prohibited to minimise risk of uncontrolled forest fires, and a reduction in traffic emissions occurs due to the vacation period in July/August. This also impacts the industrial source which is lowest in August. Finally, the fuel oil combustion source undergoes a similar variation to that of secondary sulphate, as this source would be influenced by the same factors. Furthermore, as noted previously, sea breeze circulation is substantially more influential during the summer months (Pey et al., 2009a). Therefore, shipping emissions are likely to be more influential owing to the enhanced sea breezes and may provide some explanation of the seasonality observed for the fuel oil combustion source. Furthermore, the presence of sulphate (19\% of the variance) and ammonium $(24 \%)$ in this source likely accounts for some of the seasonal variation observed in the fuel oil combustion source.

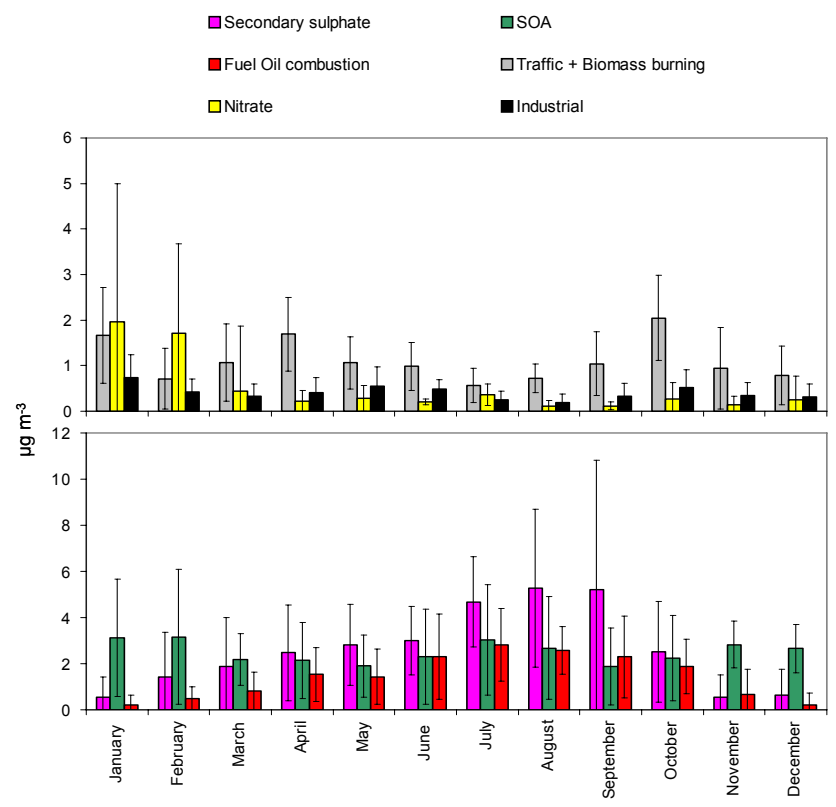

Fig. 6. Average monthly concentrations $\left(\mu \mathrm{g} \mathrm{m}^{-3}\right)$ of each source.

\subsection{Particle number concentrations}

Average particle number concentrations $\left(\mathrm{N}_{9-825} \mathrm{~nm}\right)$ for the entire measurement period (5/11/2010 to $01 / 06 / 2011$ and from 15/10/2011 to $18 / 12 / 2011$ ) were $3097 \mathrm{~cm}^{-3}$. While median values or geometric means are normally considered better suited for analysis of particle number size distributions to avoid giving too much weight to outlier values, arithmetic means are used here because $\mathrm{PM}_{1}$ and its chemical components are daily averages, and outlier values occurring during $24 \mathrm{hr}$ sampling can affect these concentrations similarly. For this reason, arithmetic mean particle number concentrations are reported in order to include, for example, short-lived or sudden changes in concentrations that would similarly affect $\mathrm{PM}_{1}$ concentrations, $\mathrm{BC}$, gaseous pollutants etc.

The Aitken mode $\left(\mathrm{N}_{30-100}\right)$ is the dominant particle mode with average concentrations of $1601 \mathrm{~cm}^{-3}$, followed by the accumulation mode $\left(\mathrm{N}_{100-825}\right)$ at $881 \mathrm{~cm}^{-3}$. The nucleation mode $\left(\mathrm{N}_{9-30}\right)$ registered the lowest concentrations of $616 \mathrm{~cm}^{-3}$. A comparison of particle number concentrations measured at various sites across Europe found mean levels to range from $2000-10000 \mathrm{~cm}^{-3}$ for continental boundary layer sites (Spracklen et al., 2010). Comparisons with particle number concentrations reported in that study suggest that levels at MSY most closely reflect those measured in Schauinsland, Germany $\left(2772 \mathrm{~cm}^{-3}\right)$, which is a mid-level mountain station affected by regional pollution under certain conditions, similarly to MSY. Data was not available to include in this study from June to October, but there is evidence to suggest that summer concentrations of particles are substantially higher in summer at MSY. Thus, the mean annual particle number concentration given in this study is 
likely to be underestimated due to the omission of summer measurements. This should be taken into consideration when comparing particle number concentrations with other sites.

\subsection{Source contribution to ambient sub-micron number concentration}

\subsubsection{Identification of emission sources by PCA}

The measurement of particle number concentrations and their size distribution $(9-825 \mathrm{~nm})$ in tandem with detailed chemical composition of $\mathrm{PM}_{1}$ have also allowed for the identification of various sources affecting particle number concentrations. Similar studies have been performed with $\mathrm{PM}_{2.5}$ chemical constituents in an urban environment (Pey et al., 2009), but few, if any, have been performed using $\mathrm{PM}_{1}$ for a RB site. The application of PCA to the database explained $71 \%$ of the variance of the data and allowed for the identification of five principal components, as shown in Table 2, which are: industrial + traffic + biomass burning, new particle formation + growth $(\mathrm{NPF}+\mathrm{G})$, secondary sulphate + fuel oil combustion, crustal material and secondary nitrate. These sources reflect the sources described previously for PMF, but the significantly reduced dataset used in the PCA analysis (61 daily samples) compared to PMF analysis (182 daily samples) resulted in the merging of some of the emission factors described in PMF, such as occurs for industrial + traffic + biomass burning, and secondary sulphate + fuel oil combustion. Unfortunately SOA was not identified by PCA, probably also as a result of the reduced dataset and incomplete summer measurements. A larger dataset with more cases (typically more than 100 cases for a robust analysis) may allow for the separation of these sources, or indeed the identification of new sources.

The principal component of industrial + traffic + biomass burning (34\% of the total variance) exhibits high factor loadings for variables typically associated with traffic emissions ( $\left.\mathrm{EC}, \mathrm{BC}, \mathrm{OC}, \mathrm{NO}_{2}, \mathrm{Sn}, \mathrm{Sb}\right)$, industrial emissions $(\mathrm{Pb}$, $\mathrm{Zn}, \mathrm{Cd}, \mathrm{Mn}, \mathrm{Cu}$ ) and biomass burning (OC, EC, BC, K). This component is closely associated with particles of 100 $300 \mathrm{~nm}$ and $500-825 \mathrm{~nm}$ in diameter, suggesting this source mostly influences aerosol number concentrations in these two diameter ranges. Fresh emissions that are transported to MSY relatively quickly after emission would be expected to be smaller $\left(\mathrm{N}_{100-300}\right)$. Enduring regional pollution episodes, such as those that occur in winter, would promote the condensation of smaller particles onto the surface of larger particles within the aged air mass, and give rise to higher concentrations of larger particles $\left(\mathrm{N}_{500-825}\right)$.

The second component (12\% of the total variance) exists almost exclusively in the ultrafine mode $(<100 \mathrm{~nm})$ in terms of concentration, and is not associated with any component of $\mathrm{PM}_{1}$ or gaseous pollutant. However some relationship exists with temperature and solar radiation, suggesting this source is a result of photochemical nucleation and sub- sequent growth into particles of larger diameter. A negative factor loading is also observed for relative humidity (RH; 0.18 ), as RH is believed to have an inverse relationship with NPF (Hamed et al., 2011). The negative association with nitrate could indicate two alternative processes; (1) nitrate is most abundant when temperatures are lower, while on the other hand the component NPF $+\mathrm{G}$ bears some positive relationship with temperature, as evidenced in Table 2. Therefore, opposite meteorological conditions favour either the nitrate source or the NPF + G source. (2) In addition, the presence of coarse nitrate particles would act as a condensation sink and scavenge the gaseous precursors necessary for NPF. Fig. 7 highlights the opposing variation of nitrate concentrations and particle number concentrations in the nucleation mode.

Secondary sulphate + fuel oil combustion is marked by high factor loadings of ammonium sulphate and $\mathrm{V}$ and explains $10 \%$ of the variance in particle number concentration. As previously observed with PMF analysis, this factor also strongly influences $\mathrm{PM}_{1}$ concentrations, and exists across all size ranges $(100-825 \mathrm{~nm})$. The association with temperature/solar radiation is further indicative of this factor being most abundant under regional pollution episodes most typical in warmer seasons.

The component titled crustal material $(10 \%$ of the total variance) exhibits high factor loadings of $\mathrm{Ce}, \mathrm{La}, \mathrm{Fe}, \mathrm{Ni}$ and $\mathrm{Al}_{2} \mathrm{O}_{3}$. This source contributes very little to the particle number concentration, as it most likely contributes to particles between $825 \mathrm{~nm}$ and $1 \mu \mathrm{m}$ and coarse PM (not included in this study). Finally, nitrate is, similarly to that observed for $\mathrm{PMF}$, characterised by $\mathrm{NO}_{3}^{-}, \mathrm{K}$ and to a lesser extent $\mathrm{NH}_{4}^{+}$ in the range of 300-825 nm. The presence of $\mathrm{K}$ may suggest some influence of biomass burning in this factor. Temperature is negatively correlated with this source as expected. This component explains the least amount of variance of all the sources (5\%). Attention must be drawn to the presence of $\mathrm{N}_{9-30}$ in this component (factor loading of 0.18), as this is in stark contrast to the theory that the presence of nitrate adversely affects NPF. As highlighted in Fig. 7, nitrate and $\mathrm{N}_{9-30}$ are, for the most part, anti-correlated. However, situations arise (indicated by the blue arrow) whereby their variation in the time series are similar, especially when nitrate concentrations are very low, and thus, PCA has identified these two variables as bearing some relationship. Rather than the nitrate source actually contributing to the nucleation mode (as suggested in Fig. 9; top graph), this is simply a limitation of PCA, whereby two variables that undergo similar variations coincidentally are considered to be related. It may also be hypothesised that NPF is occurring before the arrival of the polluted breeze (containing nitrate), however this seems unlikely as, if this were the case, the other sources such as industrial + traffic + biomass burning or secondary sulphate would also be present. This highlights the disadvantage of using $24 \mathrm{~h} \mathrm{PM}_{1}$ chemical component concentrations rather than, ideally, hourly concentrations. 




Fig. 7. Time variation of nitrate concentration $\left(\mu \mathrm{g} \mathrm{m}^{-3}\right)$ and particle number concentration $\left(\mathrm{cm}^{-3}\right)$ of the nucleation mode $\left(\mathrm{N}_{9-30}\right)$ for the entire measurement period (above graph) and for a section of the data (below). Red arrows highlight opposing variations in concentrations and blue arrows indicate similar variations in concentrations.

Table 2. Factors/sources and factor loadings $(<1)$ identified by applying Principal Component Analysis on a dataset composed of PM 1 chemical components, particle number concentration for different size ranges, gaseous pollutant concentrations and some meteorological variables.

\begin{tabular}{|c|c|c|c|c|c|c|c|c|c|}
\hline \multicolumn{2}{|c|}{$\begin{array}{l}\text { Industrial + Traffic } \\
+ \text { Biomass burning }\end{array}$} & \multicolumn{2}{|c|}{$\begin{array}{l}\text { New particle formation } \\
+ \text { growth }(\mathrm{NPF}+\mathrm{G})\end{array}$} & \multicolumn{2}{|c|}{$\begin{array}{l}\text { Secondary Sulphate } \\
\text { + Fuel oil combustion }\end{array}$} & \multicolumn{2}{|c|}{$\begin{array}{l}\text { Crustal } \\
\text { material }\end{array}$} & \multicolumn{2}{|c|}{$\begin{array}{l}\text { Secondary } \\
\text { Nitrate }\end{array}$} \\
\hline $\mathrm{BC}$ & 0.90 & $\mathrm{~N}_{9-825}$ & 0.88 & $\mathrm{SO}_{4}^{2-}$ & 0.85 & $\mathrm{Ce}$ & 0.91 & $\mathrm{~K}$ & 0.56 \\
\hline $\mathrm{Pb}$ & 0.89 & $\mathrm{~N}_{30-50}$ & 0.92 & $\mathrm{NH}_{4}^{+}$ & 0.84 & $\mathrm{La}$ & 0.85 & $\mathrm{NO}_{3}^{-}$ & 0.51 \\
\hline $\mathrm{EC}$ & 0.86 & $\mathrm{~N}_{9-30}$ & 0.75 & $\mathrm{~N}_{300-500}$ & 0.64 & $\mathrm{Ni}$ & 0.72 & SR & -0.41 \\
\hline $\mathrm{Zn}$ & 0.84 & $\mathrm{~N}_{50-100}$ & 0.74 & $\mathrm{PM}_{1}$ & 0.74 & $\mathrm{Al}_{2} \mathrm{O}_{3}$ & 0.63 & $\mathrm{~T}$ & -0.40 \\
\hline $\mathrm{NO}_{2}$ & 0.81 & $\mathrm{~T}$ & 0.61 & $\mathrm{~V}$ & 0.59 & $\mathrm{Fe}$ & 0.46 & $\mathrm{~N}_{300-500}$ & 0.39 \\
\hline $\mathrm{Cd}$ & 0.80 & SR & 0.42 & $\mathrm{~N}_{100-300}$ & 0.40 & $\mathrm{~N}_{500-825}$ & 0.18 & $\mathrm{~N}_{500-825}$ & 0.33 \\
\hline $\mathrm{OC}$ & 0.76 & $\mathrm{~N}_{100-300}$ & 0.39 & $\mathrm{~N}_{500-825}$ & 0.36 & & & $\mathrm{NH}_{4}^{+}$ & 0.33 \\
\hline $\mathrm{N}_{100-300}$ & 0.74 & $\mathrm{NO}_{3}^{-}$ & -0.34 & $\mathrm{~T}$ & 0.39 & & & $\mathrm{~N}_{9-30}$ & 0.18 \\
\hline $\mathrm{N}_{500-825}$ & 0.72 & $\mathrm{RH}$ & -0.18 & SR & 0.34 & & & & \\
\hline $\mathrm{Sn}$ & 0.72 & & & & & & & & \\
\hline $\mathrm{Mn}$ & 0.65 & & & & & & & & \\
\hline $\mathrm{K}$ & 0.64 & & & & & & & & \\
\hline $\mathrm{Cu}$ & 0.55 & & & & & & & & \\
\hline $\mathrm{Sb}$ & 0.53 & & & & & & & & \\
\hline $\mathrm{NO}_{3}^{-}$ & 0.51 & & & & & & & & \\
\hline Eigenvalues & 11.9 & & 4.3 & & 3.8 & & 3.4 & & 2.1 \\
\hline$\%$ total var. exp. & 34 & & 12 & & 10 & & 10 & & 5 \\
\hline
\end{tabular}

\subsubsection{Contribution of each source to particle number concentration}

The application of MLRA allowed for the determination of the contribution of each factor to the total particle number concentration. As shown in Fig. 8, the component titled NPF $+\mathrm{G}$ comprises the largest part of the total par- ticle number concentration with $1715 \pm 1724 \mathrm{~cm}^{-3}(56 \%)$. As stated previously, this factor is not related to any known emission source. It is probable that the source of these particles is from new particle formation and growth, either occurring in situ or being transported to the site. The component industrial + traffic + biomass burning is the second most influential factor in terms of particle number 


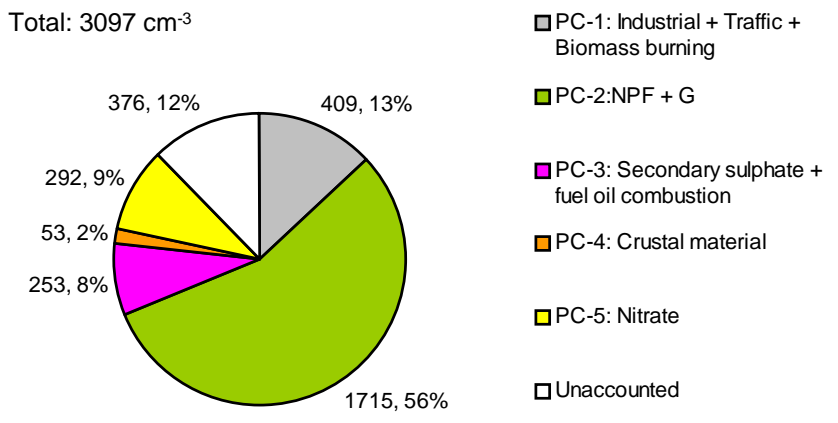

Fig. 8. Mean daily contribution to $\mathrm{N}_{9-800}\left(\mathrm{~cm}^{-3}\right.$ and $\left.\%\right)$ for the different factors identified by PCA analysis.

concentration $\left(409 \pm 654 \mathrm{~cm}^{-3} ; 13 \%\right)$, followed by the nitrate source $\left(292 \pm 344 \mathrm{~cm}^{-3} ; 9 \%\right)$. As outlined previously, the contribution of nitrate to the particle number concentration may be overestimated. Finally, the source secondary sulphate + fuel oil combustion contributes $8 \%$ to the total particle number concentration $\left(253 \pm 378 \mathrm{~cm}^{-3}\right)$, followed by crustal material $\left(53 \pm 91 \mathrm{~cm}^{-3} ; 2 \%\right)$.

Figure 9 displays the mean daily contribution of each factor to the particle number concentration for different size ranges. Furthermore, specific episodes of interest are highlighted. Episodes of pollution (WAE) are highlighted in blue, occurring from 20/01/2011 to 13/02/2011 (A), and from $22 / 03 / 2011$ to $26 / 03 / 2011$ (B). These episodes are characterised by increased solar radiation with cool temperatures (mean of $5.1^{\circ} \mathrm{C}$ and $9.4{ }^{\circ} \mathrm{C}$ for $\mathrm{A}$ and $\mathrm{B}$, respectively), and high concentrations of $\mathrm{NO}_{2}$ and $\mathrm{PM}_{1}$. During episode $\mathrm{A}$, particles of diameter $>50 \mathrm{~nm}$ dominate, with the industrial + traffic + biomass burning and nitrate sources being most significant. Interestingly, the traffic + biomass burning source identified by PMF (Fig. 9; bottom graph) does not influence the $\mathrm{PM}_{1}$ mass to the same extent as particle number concentrations. The nitrate source does influence both the mass and particle number concentration during this episode, and SOA is also substantial in the $\mathrm{PM}_{1}$ mass. The second episode (B) differs from $\mathrm{A}$ in that it is dominated by the secondary sulphate source for both particle number concentrations of diameter $>100 \mathrm{~nm}$ and also the $\mathrm{PM}_{1}$ mass. The warmer temperatures result in increased sulphate and reduced nitrate concentrations.

As is evidenced by Fig. 9, the component titled NPF + $\mathrm{G}$ undergoes a clear seasonality with levels increasing as solar radiation intensity and temperatures increase, such as occurs in April (C; highlighted in green) suggesting the sources of these particles have some relationship with photochemical reactions. Sulphate and nitrate related particles are not significant, as they would scavenge the gaseous precursors necessary for new particle formation through condensation and coagulation processes. The source of industrial + traffic + biomass burning is present in the accumulation mode however, along with elevated $\mathrm{NO}_{2}$ concentrations, suggest- ing that transport of ultrafine particles, possibly emitted by traffic and biomass burning, may also be of influence here. SOA is also abundant in the mass concentration, indicating that SOA may be influential in NPF + G. Two episodes of nucleation are highlighted by the red arrows in Fig. 9. The first, occurring on $7 / 12 / 2010$, coincides with elevated concentrations of SOA and relatively little contribution from the other sources. The second, on the 28/05/2011, coincides with elevated concentrations of SOA, secondary sulphate and $\mathrm{PM}_{1}$, indicating that nucleation can occur at this site even in the presence of high concentrations of background coarse particles.

An episode of regional pollution during the warmer period is highlighted in red $\left(\mathrm{D}\right.$; mean temperature of $\left.13^{\circ} \mathrm{C}\right)$ in Fig. 9, when sulphate particles are at their highest concentrations. Particle number concentrations are generally very low, and particles of diameter $>300 \mathrm{~mm}$ dominate as a result of particle interaction through coagulation and condensation within the air mass. $\mathrm{PM}_{1}$ concentrations are high and $\mathrm{PM}_{1}$ is also comprised significantly of the secondary sulphate source. Once again, NPF $+\mathrm{G}$ is negligible owing to the high background concentrations of larger sulphate particles.

Figure 10 displays the mean particle number size distribution recorded over the measurement period, with the majority of particles existing in the Aitken mode $\left(\mathrm{N}_{30-100}\right)$. Furthermore, the mean contribution of each component to the particle number concentration for various size bins is also shown. Beginning with the smallest particles $\left(\mathrm{N}_{9-30}\right)$, the NPF + $\mathrm{G}$ source contributes the majority of particles in this range. The nitrate source, as observed in Fig. 8, contributes a significant number of particles to this mode, owing to an artefact caused by the limitation of the current analysis, as described previously. In a similar way, the component called crustal material was also found to artificially contribute particles to this mode. One would expect crustal material to contribute little to particle number concentration as it mostly found in the coarse mode and only contributes $3 \%$ to $\mathrm{PM}_{1}$ mass. As observed during PMF analysis, a significant proportion of crustal material was identified in the source SOA, owing to meteorological conditions which favour increased concentrations of both SOA and crustal material. Although SOA was not identified by PCA to contribute to particle number concentration, the presence of crustal material in the nucleation mode may be related to the fact that SOA and crustal material are controlled by similar conditions, and SOA could contribute to the growth of nucleating particles (O'Dowd et al., 2002b). NPF $+\mathrm{G}$ dominates particle number concentrations below $100 \mathrm{~nm}$ and, to a lesser extent proportionally, to particles between $100-300 \mathrm{~nm}$, as continued growth into particles of this size is less likely. The influence of transport of nanoparticles may be influential; especially considering that the highest particle number concentrations for NPF $+\mathrm{G}$ were recorded for $\mathrm{N}_{30-100}$, indicating that this source is not just from local NPF, but also from transport of newly formed 


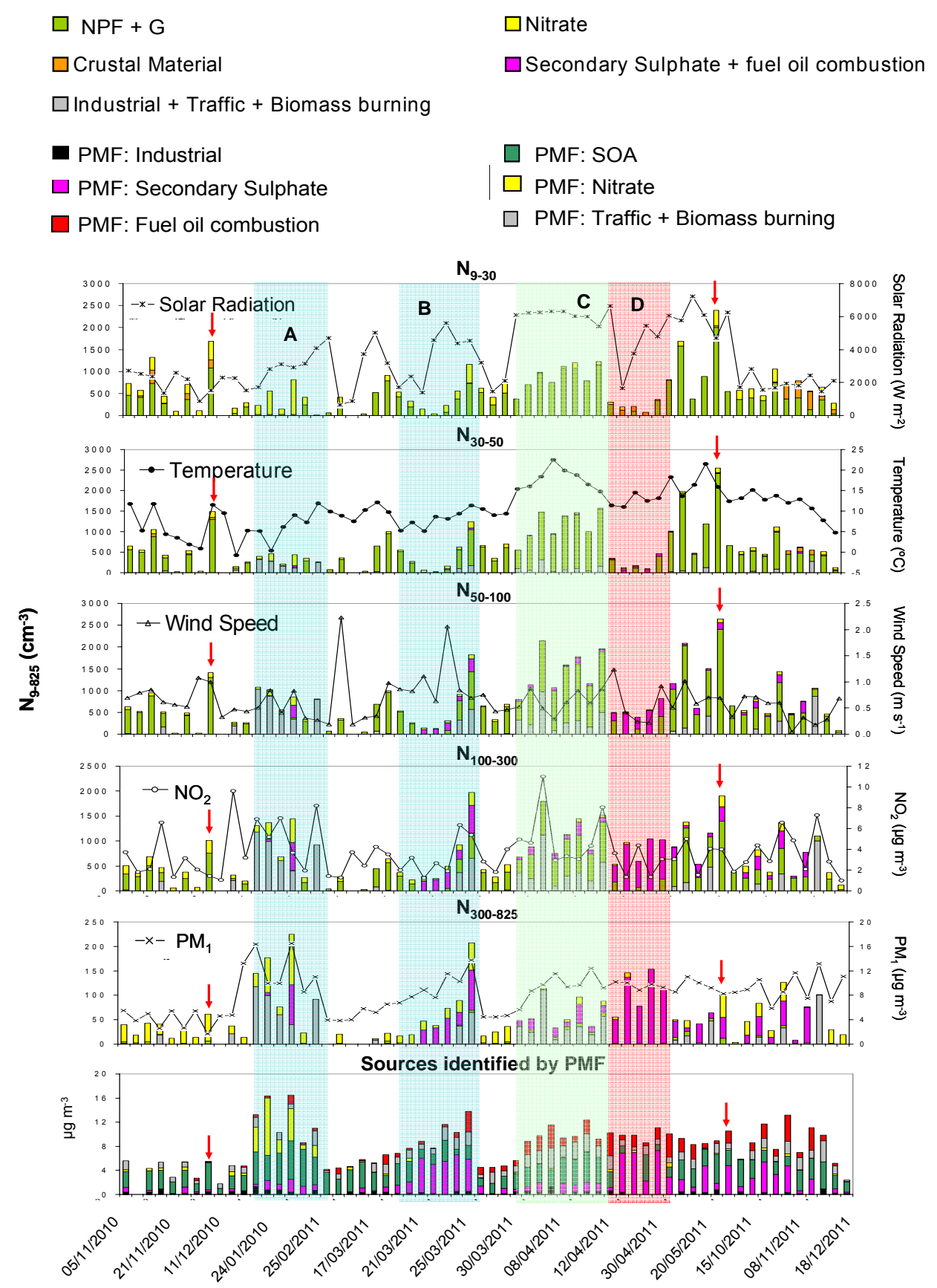

Fig. 9. Mean daily contribution of each source to the particle number concentration in various size ranges $\left(\mathrm{N}_{9-825}\left(\mathrm{~cm}^{-3}\right)\right)$ identified by PCA analysis. Specific aerosol episodes are highlighted: blue (A, B; WAE), green (C; NPF), red (D; summer regional recirculation). The bottom graph shows the source contribution of factors identified by PMF for the same days. Occurrence of intense NPF are highlighted by the red arrow.

particles to the site. Industrial + traffic + biomass burning begins to emerge in the size ranges $\mathrm{N}_{30-50}$ and its influence increases with increasing diameter. As expected, secondary sulphate and nitrate particles are present in the larger ranges, contributing much less to the overall particle number, but significantly to the mass.

\section{Conclusions}

The levels and chemical composition of $\mathrm{PM}_{1}$ recorded at the RB site of MSY over a period of almost 2.5 years are presented in this work. $\mathrm{PM}_{1}$ mass at MSY is dominated by $\mathrm{OM}$ and secondary sulphate. Concentrations of chemical components were found to undergo a clear seasonality 


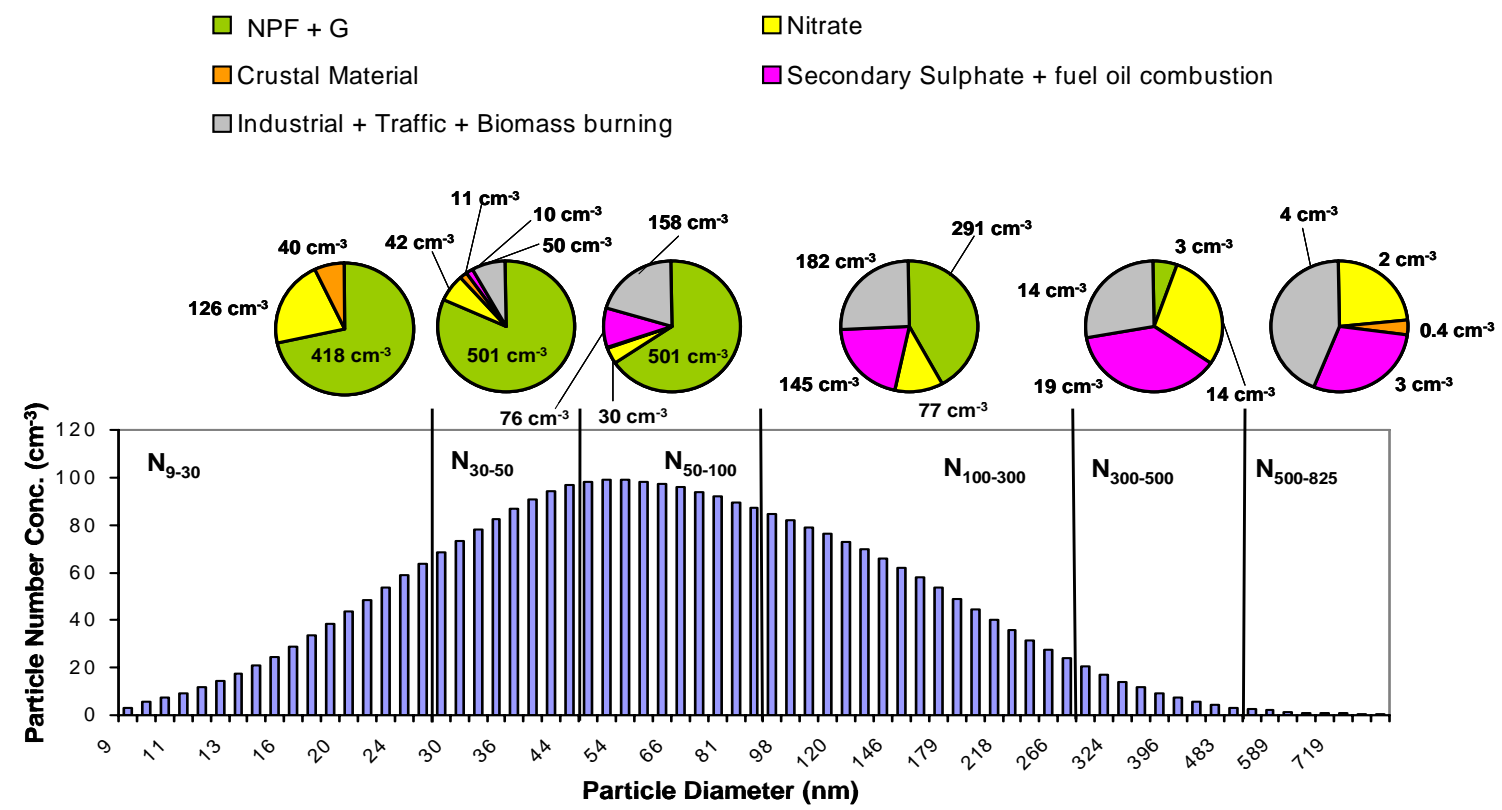

Fig. 10. Mean size distribution for particle concentrations $\left(\mathrm{cm}^{-3}\right)$ recorded at MSY and the corresponding contribution of each PC to the particle number concentration for various size groups $\left(\mathrm{N}_{9-30}, \mathrm{~N}_{30-50}, \mathrm{~N}_{50-100}, \mathrm{~N}_{100-300}, \mathrm{~N}_{300-500}, \mathrm{~N}_{500-825}\right)$.

with highest concentrations recorded in summer for OM, sulphate, ammonium and crustal material owing to the regional recirculation of air masses and, in the case of OM, from higher biogenic emissions. Nitrate concentrations were at their highest in winter, as was the marine aerosol. The identification of emission sources that contribute to $\mathrm{PM}_{1}$ were identified using PMF. Six sources were identified, namely; secondary sulphate, traffic + biomass burning, industrial, SOA, secondary nitrate and fuel oil combustion. The secondary sulphate source accounted for the largest variance in $\mathrm{PM}_{1}(32 \%)$, and was characterised by sulphate and ammonium. This source was most abundant in summer owing to higher insolation and air mass recirculation across the region, favouring the accumulation of pollutants emitted over a larger area. The SOA source was the second most important source in terms of mass, accounting for $28 \%$ of the total variance, and was identified by the presence of OC (explaining $43 \%$ of the variance in OC). SOA can be from both a natural source, such as biogenic emissions, or from anthropogenic emissions which are most influential during winter anticyclonic pollution episodes. Species associated with crustal material were found in both the secondary sulphate and SOA sources, as the meteorological conditions that favour these sources would also favour elevated levels of crustal material. Secondary nitrate was identified as a source with most influence on PM during winter, with highest concentrations in January and February. The traffic + biomass burning source was identified by the presence of typical traffic tracers (EC, $\mathrm{OC}, \mathrm{Sb}$ and $\mathrm{Sn}$ ) and biomass burning tracer $\mathrm{K}$. This factor accounted for $78 \%$ of the total variance of EC and $26 \%$ of $\mathrm{K}$. Concentrations were observed to be highest in January,
April and October, as a result of local biomass burning emissions and winter pollution episodes. An industrial source was identified by the presence of typical tracers associated with industrial emissions such as $\mathrm{Pb}, \mathrm{As}, \mathrm{Cd}, \mathrm{Sn}, \mathrm{Cu}, \mathrm{Zn}, \mathrm{Cr}, \mathrm{Fe}$ and $\mathrm{Mn}$. This factor contributed little mass to $\mathrm{PM}_{1}$, accounting for only $4 \%$ of the total variance. A decrease in industrial emissions was observed in August owing to reduced industrial activity during the vacation period. Finally, a fuel oil combustion source was easily identifiable by the presence of $\mathrm{V}$ and $\mathrm{Ni}$ which are known emissions specific to fuel oil combustion.

Average particle number concentrations at MSY for the period $05 / 11 / 2010$ to $01 / 06 / 2011$ and from $15 / 10 / 2011$ to $18 / 12 / 2011$ were $3097 \mathrm{~cm}^{-3}$, with the Aitken mode $\left(\mathrm{N}_{30-100}\right)$ being the dominant mode (52\% of the total particle number concentration). Principle Component Analysis of the particle number concentration for various size bins, coupled with chemical speciation data, gaseous pollutant concentrations and a range of meteorological data allowed for the identification of 5 factors affecting ambient particle number concentrations. These five factors reflected those identified by PMF, but some of the sources merged owing to the reduced data set. The five principal components identified were; industrial + traffic + biomass burning, NPF $+\mathrm{G}$, secondary sulphate + fuel oil combustion, crustal material and nitrate. The source of industrial + traffic + biomass burning explained $34 \%$ of the variance and was characterised by tracers associated with traffic emissions (EC, BC, OC, $\mathrm{NO}_{2}, \mathrm{Sn}, \mathrm{Sb}$ ), industrial emissions ( $\left.\mathrm{Pb}, \mathrm{Zn}, \mathrm{Cd}, \mathrm{Mn}, \mathrm{Cu}\right)$ and biomass burning (OC, EC, BC, K). The second most important component (12\% of the total variance) was NPF + 
G. This component was not observed to be associated with any other parameter except for temperature and solar radiation, suggesting that this source may be influenced by new particle formation due to the high loading of particle concentrations in the nucleation mode. The use of multilinear regression analysis allowed for the calculation of the contribution of each source to the daily particle number concentration. The NPF $+\mathrm{G}$ source was the largest contributor to the total particle number concentration, explaining $56 \%$ of the total concentration. Furthermore, NPF $+\mathrm{G}$ dominated particle concentrations below $100 \mathrm{~nm}$, but its influence diminished for particles $>100 \mathrm{~nm}$. Episodes of elevated influence of $\mathrm{NPF}+\mathrm{G}$ were identified during periods of more intense solar radiation and decreased levels of the nitrate and sulphate sources. Three episodes of prolonged pollution were identified, two in winter and the other in late spring. The winter pollution episodes were characterised by the industrial + traffic + biomass burning source and the nitrate source. Conversely, the spring regional pollution episode was mostly influenced by secondary sulphate particles. An artefact highlighting the limitation of MLRA for particle number concentrations was identified by the presence of the nitrate source in the nucleation mode, which was a result of coincidental parallel variations in $24 \mathrm{~h}$ nitrate concentrations and nucleation mode particle concentrations.

The utilisation of two source apportionment techniques for fine PM and chemical components, namely PMF and PCA, in conjunction with sub-micrometer particle number concentrations has allowed for the identification of the various sources affecting aerosols at MSY. Such a novel approach has highlighted the broad range of processes and sources that can influence aerosols at the site.

Acknowledgements. This study was supported by the Ministry of Economy and Competitiveness and FEDER funds under the projects CARIATI (CGL2008-06294/CLI), VAMOS (CGL2010 19464/CLI) and GRACCIE (CSD 2007-00067). The research leading to these results has received funding from the European Union Seventh Framework Programme (FP7/2007-2013) ACTRIS under grant agreement no. 262254 and the Generalitat de Catalunya (AGRUAR-2009SGR8). The authors would like to extend their gratitude to Jesús Parga and Jordi Gil for their technical support.

Edited by: E. Gerasopoulos

\section{References}

Amato, F., Pandolfi, M., Viana, M., Querol, X., Alastuey, A., Moreno, T.: Spatial and chemical patterns of PM10 in road dust deposited in urban environment, Atmos. Environ., 43, 16501659, 2009.

Belis, C. A., Karagulian, F., Larsen, B. R., and Hopke, P. K.: Critical review and meta-analysis of ambient particulate matter source apportionment using receptor models in Europe, Atmos. Environ., 69, 94-108, 2013.

Bourcier, L., Sellegri, K., Chausse, P., and Pichon, J. M.: Seasonal variation of water-soluble inorganic components in aerosol sizesegregated at the puy de Dôme station (1465 m.a.s.1.), France, J. Atmos. Chem., 69, 47-66, 2012.

Cavalli, F., Viana, M., Yttri, K. E., Genberg, J., and Putaud, J. P.: Toward a standardised thermal-optical protocol for measuring atmospheric organic and elemental carbon: the EUSAAR protocol, Atmos. Meas. Tech., 3, 79-79, 2010, http://www.atmos-meas-tech.net/3/79/2010/.

Cozic, J., Verheggen, B., Weingartner, E., Crosier, J., Bower, K. N., Flynn, M., Coe, H., Henning, S., Steinbacher, M., Henne, S., Collaud Coen, M., Petzold, A., and Baltensperger, U.: Chemical composition of free tropospheric aerosol for PM1 and coarse mode at the high alpine site Jungfraujoch, Atmos. Chem. Phys., 8, 407-423, doi:10.5194/acp-8-407-2008, 2008.

Cusack, M., Alastuey, A., Pérez, N., Pey, J., and Querol, X.: Trends of particulate matter $\left(\mathrm{PM}_{2.5}\right)$ and chemical composition at a regional background site in the Western Mediterranean over the last nine years (2002-2010), Atmos. Chem. Phys., 12, 8341-8357, doi:10.5194/acp-12-8341-2012, 2012.

Hamed, A., Korhonen, H., Sihto, S.-L., Joutsensaari, J., Järvinen, H., Petäjä, T., Arnold, F., Nieminen, T., Kulmala, M., Smith, J. N., Lehtinen, K. E. J., and Laaksonen, A.: The role of relative humidity in continental new particle formation, J. Geophys. Res., 116, D03202, doi:10.1029/2010JD014186, 2011.

Harrison, R. M. and Pio, C.: Size differentiated composition of inorganic aerosol of both marine and continental polluted origin, Atmos. Environ., 17, 1733-1738, 1983.

Harrison, R. M., Beddows, D. C. S., and Dall'Osto, M.: PMF analysis of Wide-Range Particle Size Spectra Collected on a Major Highway, Environ. Sci. Tech., 45, 5522-5528, 2011.

IPCC: Climate Change 2007: The Physical Science Basis, Contribution of Working Group I to the Fourth Assessment Report of the IPCC, ISBN 9780521 88009-1 Hardback; 9780521 70596-7 Paperback, 2007.

Lighty, J. S., Veranth, J. M., and Sarofim, A. F.: Combustion aerosols: factors governing their size and composition and implications to you human health, J. Air Waste Manag., 50, 15651618, 2000.

Minguillón, M. C., Querol, X., Baltensperger, U., and Prévôt, A. S. H.: Fine and coarse PM composition and sources in rural and urban sites in Switzerland: Local or regional pollution? Sci. Total Environ., 427-428, 191-202, 2012. 
Minguillón, M. C., Perron, N., Querol, X., Szidat, S., Fahrni, S. M., Alastuey, A., Jimenez, J. L., Mohr, C., Ortega, A. M., Day, D. A., Lanz, V. A., Wacker, L., Reche, C., Cusack, M., Amato, F., Kiss, G., Hoffer, A., Decesari, S., Moretti, F., Hillamo, R., Teinilä, K., Seco, R., Peñuelas, J., Metzger, A., Schallhart, S., Müller, M., Hansel, A., Burkhart, J. F., Baltensperger, U., and Prévôt, A. S. H.: Fossil versus contemporary sources of fine elemental and organic carbonaceous particulate matter during the DAURE campaign in Northeast Spain, Atmos. Chem. Phys., 11, 12067-12084, doi:10.5194/acp-11-12067-2011, 2011.

O’Dowd, C. D., Aalto, P., Hmeri, K., Kulmala, M., and Hoffman, T.: Aerosol formation: atmospheric particles from organic vapours, Nature, 416, 497-498, 2002b.

Öztürk, F., Zararsiz, A., Dutkiewicz, V. A., Husain, L., Hopke, P. K., Tuncel, G.: Temporal variations and sources of Eastern Mediterranean aerosols based on a 9-year observation, Atmos. Environ., 61, 463-475, 2012.

Paatero, P. and Tapper, U.: Positive matrix factorisation: a nonnegative factor model with optimal utilisation of error estimates of data values, Environmetrics, 5, 111-26, 1994.

Pandolfi, M., Gonzalez-Castanedo, Y., Alastuey, A., de la Rose, J. D, Mantilla, E., de la Campa, A. S., Querol, X., Pey, J., Amato, F., and Moreno, T.: Source apportionment of PM10 and PM2.5 at multiple sites in the strait of Gibraltar by PMF: Impact of shipping emissions, Environ. Sci. Poll. Res., 18, 260-269, 2011.

Pérez, N., Pey, J., Castillo, S., Viana, M., Alastuey, A., Querol, X.: Interpretation of the variability of levels of regional background aerosols in the Western Mediterranean, Sci. Total Environ., 407, 524-540, 2008.

Pey, J., Rodríguez, S., Alastuey, A., Moreno, T., Putaud, J. P., and Van Dingenen, R.: Variations of urban aerosols in the Western Mediterranean, Atmos. Environ., 42, 9052-9062, 2008.

Pey, J., Pérez, N., Castillo, S., Viana, M., Moreno, T., Pandolfi, M., López-Sebastián, J.M., Alastuey, A., Querol, X.: Geochemistry of regional background aerosols in the Western Mediterranean, Atmos. Res., 94, 422-435, 2009a.

Pey, J., Querol, X., Alastuey, A., Rodríguez, Putaud, J.P., Van Dingenen, R.: Source apportionment of urban fine and ultra-fine particle number concentration in a Western Mediterranean city, Atmos. Environ. 43, 4407-4415, $2009 \mathrm{~b}$.

Pey, J., Pérez, N., Querol, X., Alastuey, A., Cusack, M., Reche, C.: Intense winter pollution episodes affecting the Western Mediterranean, Sci. Total Environ., 408, 1951-1959, 2010.

Pope, C. A. and Dockery, D. W.: Health effects of fine particulate air pollution: lines that connect, J. Air. Waste Manage., 56(6), 709-42, 2006.

Querol, X., Alastuey, A., Rodríguez, S., Plana, F., Mantilla, E., Ruiz, C.R.: Monitoring of PM10 and PM2.5 around primary particulate anthropogenic emission sources, Atmos. Environ., 35, 845-858, 2001.

Querol, X., Alastuey, A., Pey, J., Cusack, M., Mihalopoulos, N., Theodosi, C., Gerasopoulos, E., Kubilay, N., Koçak, M.: Variability in regional background aerosols in the Mediterranean, Atmos. Chem. Phys., 9, 4575-4591, 2009,

http://www.atmos-chem-phys.net/9/4575/2009/.
Richard, A., Gianini, M.F.D., Mohr, C., Furger, M., Bukowiecki, N., Minguillón, M.C., Lienemann, P., Flechsig, U., Appel, K., DeCarlo, P.F., Heringa, M.F., Chirico, R., Baltensperger, U., Prévôt, A.S.H.: Source apportionment of size and time resolved trace elements and organic aerosols from an urban courtyard site in Switzerland, Atmos. Chem. Phys., 11, 8945-8963, 2011, http://www.atmos-chem-phys.net/11/8945/2011/.

Rodríguez, S., Querol, X., Alastuey, A., Viana, M., and Mantilla E.: Events affecting levels and seasonal evolution of airborne particulate matter concentrations in the Western Mediterranean, Environ. Sci. Technol., 37, 216-222, 2003.

Rodríguez, S., Van Dingenen, R., Putaud, J.P., Dell'Acqua, A., Pey, J., Querol, X., Alastuey, A., Chenery, S., Ho, K.F., Harrison, R., Tardivo, R., Scarnato, B., Gemelli, V.: A study on the relationship between mass concentrations, chemistry and number size distribution of urban fine aerosols in Milan, Barcelona and London, Atmos. Chem. Phys., 7, 2217-2232, 2007, http://www.atmos-chem-phys.net/7/2217/2007/.

Seco, R., Peñuelas, J., Filella, I., Llusiá, J., Molowny-Horas, R., Schallhart, S., Metzger, A., Müller, M., Hansel, A.: Contrasting winter and summer VOC mixing ratios at a forest site in the Western Mediterranean Basin: The effect of local biogenic emissions, Atmos. Chem. Phys., 11, 20389-20431, 2011, http://www.atmos-chem-phys.net/11/20389/2011/.

Spindler, G., Brüggemann, E., Gnauk, T., Grüner, A., Müller, K., Herrmann, H.: A four-year size-segregated characterisation of particles $\mathrm{PM}_{10}, \mathrm{PM}_{2.5}$ and $\mathrm{PM}_{1}$ depending on air mass origin at Melpitz, Atmos. Environ., 44, 164-173, 2010.

Spracklen, D. V., Carslaw, K. S., Merikanto, J., Mann, G. W., Reddington, C.L., Pickering, S., Ogren, J.A., Andrews, E., Baltensperger, U., Weingartner, E., Boy, M., Kulmala, M., Laakso, L., Lihavainen, H., Kivekäs, Komppula, M., Mihalopoulos, N., Kouvarakis, G., Jennings, S. G., O’Dowd, C., Birmili, W., Wiedensohler, A., Weller, R., Gras, J., Laj, P., Sellegri, K., Bonn, B., Krejci, R., Laaksonen, A., Hamed, A., Minikin, A., Harrison, R. M., Talbot, R., and Sun, J.: Explaining global surface aerosol number concentrations in terms of primary emissions and particle formation, Atmos. Chem. Phys., 10, 4775-4793, 2010,

http://www.atmos-chem-phys.net/10/4775/2010/.

Thompson, M. and Howarth, R. J.: Duplicate analysis in geochemical practice. Part I. Theoretical approach and estimation of analytical reproducibility, Analyst, 101, 690-698, 1976.

Thurston, G. D. and Spengler, J. D.: A quantitative assessment of source contribution to inhalable particulate matter pollution in the Metropolitan Boston, Atmos. Environ., 19, 9-25, 1985.

Turpin, B. J. and Lim, H. J.: Species contributions to PM2.5 mass concentrations: Revisiting common assumptions for estimating organic mass, Aerosol Sci. Technol., 35, 602-610, 2001.

Vecchi, R., Chiari, M., D’Alessandro, A., Fermo, P., Lucarelli, F., Mazzei, F., Nava, S., Piazzalunga, A., Prati, P., Silvani, F., and Valli, G.: A mass closure and PMF source apportionment study on the sub-micron sized aerosol fraction at urban sites in Italy, Atmos. Environ., 42, 2240-2253, 2008.

Viana, M., Querol, X., Alastuey, A., Gil, J. I., and Menéndez, M.: Identifiaction of PM sources by principal component analysis (PCA) coupled with wind direction data, Chemosphere, 65, 2411-2418, 2006. 